\title{
Substantial Evidences Indicate That Inorganic Arsenic Is a Genotoxic Carcinogen: a Review
}

\author{
Jinia Sinha Roy, Debmita Chatterjee, Nandana Das and Ashok K. Giri \\ Molecular Genetics Division, CSIR-Indian Institute of Chemical Biology, Kolkata, India
}

\begin{abstract}
Arsenic is one of the most toxic environmental toxicants. More than 150 million people worldwide are exposed to arsenic through ground water contamination. It is an exclusive human carcinogen. Although the hallmarks of arsenic toxicity are skin lesions and skin cancers, arsenic can also induce cancers in the lung, liver, kidney, urinary bladder, and other internal organs. Arsenic is a non-mutagenic compound but can induce significant cytogenetic damage as measured by chromosomal aberrations, sister chromatid exchanges, and micronuclei formation in human systems. These genotoxic end points are extensively used to predict genotoxic potentials of different environmental chemicals, drugs, pesticides, and insecticides. These cytogenetic end points are also used for evaluating cancer risk. Here, by critically reviewing and analyzing the existing literature, we conclude that inorganic arsenic is a genotoxic carcinogen.
\end{abstract}

Key words: Inorganic arsenic, Genotoxicity, Micronucleus, Chromosomal aberrations

\section{INTRODUCTION}

Arsenic (As) exposure is a major pandemic concern, with the number of arsenic-affected nations rising to seventy, including India, Bangladesh, Japan, China, USA, Argentina, Chile, Mexico, and Taiwan, among others (1). In India, 7 states are reported to be affected by ground water arsenic contamination, and approximately 30 million individuals are consuming arsenic laden drinking water (2). Chronic arsenic exposure is associated with several deleterious outcomes including cancers and death. Dermatological manifestations including raindrop hypopigmentation, hyper-pigmentation, palmo-palmer hyper-keratosis, Bowens disease (BD), basal cell carcinoma (BCC), and squamous cell carcinoma (SCC), which are considered hallmarks of chronic arsenic toxicity (3). Interestingly, only $15-20 \%$ of individuals exposed to arsenic show

Correspondence to: Ashok K. Giri, Molecular Genetics Division, CSIR-Indian Institute of Chemical Biology, 4, Raja S. C. Mullick Road, Jadavpur, Kolkata - 700 032, India

E-mail: akgiri15@yahoo.com, akgiri@iicb.res.in

This is an Open-Access article distributed under the terms of the Creative Commons Attribution Non-Commercial License (http:// creativecommons.org/licenses/by-nc/3.0) which permits unrestricted non-commercial use, distribution, and reproduction in any medium, provided the original work is properly cited. arsenic-induced skin lesions (2). This indicates that genetic variability and other underlying factors play an important role in arsenic susceptibility. Metabolism of arsenic within human cells utilizes several methyl moieties of S-adenosyl methionine (SAM) affecting the epigenetic profile of the genome in response to arsenic. In the presence of the arsenite-methyl transferase (As3MT) enzyme, the methyl group from SAM is transferred to inorganic arsenic. This enzyme-linked process generates reactive oxygen species (ROS) which contributes to several health outcomes including cancer of the liver, skin, lungs, and other internal organs. In addition, ROS induce genotoxic stress in the form of DNA damage, cell cycle arrest, and apoptosis $(4,5)$. Moreover, undulation in the epigenetic profile within DNA and histones alters the chromatin landscape within the cells. Epigenetic regulation by histone methylation has an important functional significance in chromatin compaction and contributes to the degree to which chromatin is present heterochromatin or euchromatin (6). In our previous studies, we observed the impact of arsenic on promoter DNAmethylation pattern alteration. In another study we found that the tumor suppressor genes $p 16$ and death-associated protein kinase $(D A P K)$ were downregulated due to promoter hypermethylation (7). In addition, the interaction between excision repair cross-complementation group 2/ Cdk-activating kinase complex (ERCC2/CAK) with tran- 
scription factor IIH (TFIIH) was inhibited by promoter hypomethylation of ERCC2, resulting in disruption of p53 phosphorylation, which impaired DNA damage recognition in arsenic exposed individuals (8).

Biomarkers are extensively used in establishing and identifying biological effects of carcinogen exposure. Cytogenetic biomarkers such as chromosomal aberrations (CA), sister chromatid exchanges (SCE), or micronuclei formation $(\mathrm{MN})$ are traditionally used for bio-monitoring genotoxic effects in humans (9-11). These cytogenetic endpoints are extensively used to identify the genotoxic potentials of toxic compounds and for cancer risk assessment. The micronuclei assay (MN assay) is a popular assay for evaluation of genotoxicity due to speed, ease of use of the technique, and lack of requirement of cells in metaphase. $\mathrm{MN}$ is a cytoplasmic inclusion within a cell (a miniature nucleus), which is formed by either a chromosomal break or due to lagging movement of any chromosome or chromatid during cytokinesis. Arsenic toxicity ROS production, which contributes to shearing of the phosphate backbone of nucleic acids, resulting in chromosomal breaks $(12,13)$. $\mathrm{MN}$ assay from three different cell types: peripheral lymphocytes, urothelial, and oral epithelial cells, are good predictors as biomarkers of genotoxicity (14). Most studies that utilized $\mathrm{MN}$ assay were performed using urothelial cells (13). Urinary bladder serves as an appropriate index to monitor the genotoxicity induced by arsenic because cells collected for the MN Assay are collected from the target tissue (the bladder) which should allow for more sensitivity in detecting arsenic effects (15). In addition, cells from the urinary bladder are easy to collect. Moreover, MN in urothelial cells was ranked second based on review of 13 global studies (13).

Recently, whether arsenic is a genotoxic carcinogen has been questioned (16). In the trivalent methylated form, arsenic has been shown to be a potent genotoxic carcinogen that induces DNA damage, including chromosome breakage and numerical chromosome changes (aneuploidy). However, arsenic is not a point mutagen (17). As arsenic is an exclusive human carcinogen, we have evaluated the existing literature on genotoxic effects of inorganic arsenic in multiple human test systems to determine the genotoxic potential of inorganic arsenic on human test systems both in vitro and in vivo. The goal of this review is to conclude whether inorganic arsenic is a genotoxic or nongenotoxic carcinogen.

\section{GENOTOXIC POTENTIAL OF INORGANIC ARSENIC}

Arsenic is non-mutagenic in nature as it lacks the ability to cause point mutations. However, the genotoxic potential of arsenic lies mainly with the ability to generate ROS (18). ROS form various adducts with DNA and can also cause oxidative damage to the DNA backbone leading to breaks and subsequent $\mathrm{CA}$ and $\mathrm{MN}$ formation as observed in humans chronically exposed to arsenic (19-21). A study conducted in Mongolia with subjects chronically exposed to arsenic showed that expression of 8-oxoguanine DNA glycosylase (OGG1) was proportionally increased with increase in arsenic concentrations up to $149 \mu \mathrm{g} / \mathrm{L}(149 \mathrm{ppb})$. OGG1 is required for removal of $8 \mathrm{OHdG}$ implying that increased arsenic exposure leads to generation of $8 \mathrm{OHdG}$ in humans, necessitating increased expression of OGG1 (22). A recent study comparing OGG1-deficient mouse embryonic fibroblast (MEF) cells with the wildtype cells revealed that OGG1 null cells are more inefficient in repairing the DNA damage than wildtype cells. Consequently, the OGG1 null cells over-expressed the arsenic metabolizing enzyme As3MT as an adaptive mechanism, conferring significant resistance to inorganic arsenicinduced cell death at the cost of accumulating high levels of DNA damage due to impaired repair. Accumulation of DNA damage may lead to carcinogenic outcomes of arsenic exposure (23). Studies have reported arsenic-induced genotoxicity in humans exposed to chronic high doses of arsenic at levels much greater than the recommended WHO limit of $10 \mu \mathrm{g} / \mathrm{L}(2,24,25)$. Recent studies have demonstrated that generation of ROS combined with reduced efficiency of DNA repair contributes to DNA damage resulting from arsenic, leading to observed genotoxic effects in humans $(8,26)$.

\section{GENOTOXICITY STUDIES OF INORGANIC ARSENIC ON HUMAN CELLS IN VITRO}

Recent in vitro studies analyzing the genotoxic potential of arsenicals using the conventional methods of CA, $\mathrm{MN}, \mathrm{SCE}$, and DNA damage in human cells are summarized in Table 1. The in vitro studies listed used different forms of inorganic arsenic such as arsenate, arsenite, and arsenic trioxide. In a classic study, Petres et al. (27) analyzed chromosomes of lymphocyte cultures from healthy people treated with sodium arsenate, and observed CA on par with patients who had been exposed to arsenic decades in the past (27). Nakamuro and Sayato (28) compared the cytogenetic effects of trivalent and pentavalent arsenic in cultured lymphocytes and fibroblasts. They found that CA induced by trivalent arsenic was significantly higher than by pentavalent arsenic. They also found that frequency of CA increased with increasing dose of both trivalent and pentavalent arsenicals. Vega et al. (29) reported an aneugenic effect and CA induced by sodium arsenite in whole blood culture. They concluded that sodium arsenite induced dose-dependent aneuploidogenic effects and also induced significant $\mathrm{CA}$ in vitro. These results indicate that sodium arsenite causes mitotic arrest and aneuploidogenic effect. Similarly, aneuploidy-inducing effects of inorganic arse- 
Table 1. Inorganic arsenic induced genotoxic effects on human cells in vitro

\begin{tabular}{|c|c|c|c|c|c|}
\hline Test systems & Arsenic species & End points & Effects & $\begin{array}{l}\text { Dose } \\
\text { response }\end{array}$ & References \\
\hline Human lymphocytes & Sodium Arsenite & $\mathrm{CA}$ & + & + & Petres et al. (27) \\
\hline Human lymphocytes & $\begin{array}{l}\text { Sodium Arsenite } \\
\text { and Sodium Arsenate }\end{array}$ & SCE & + & + & Zanzoni and Jung (37) \\
\hline Human lymphocytes & $\begin{array}{l}\text { Sodium Arsenite } \\
\text { and Sodium Arsenate }\end{array}$ & $\mathrm{CA}$ & + & + & Nordenson et al. (38) \\
\hline Human lymphocytes & $\begin{array}{l}\text { Sodium Arsenite, } \\
\text { Sodium Arsenate } \\
\text { and Arsenic trioxide }\end{array}$ & $\mathrm{CA}$ & + & + & Nakamuro and Sayoto (28) \\
\hline Human lymphocytes & $\begin{array}{l}\text { Sodium Arsenite } \\
\text { and Sodium Arsenate }\end{array}$ & SCE & + & + & Crossen (40) \\
\hline $\begin{array}{l}\text { Human lymphocytes and } \\
\text { Human fibroblast }\end{array}$ & Sodium Arsenite & $\mathrm{CA}$ & + & + & Huang et al. $(31,32)$ \\
\hline Human lymphocytes & Sodium Arsenite & SCE & + & - & Sahu et al. (41) \\
\hline Human lymphocytes and fibroblast & Sodium Arsenite & $\mathrm{CA}, \mathrm{SCE}$ & + & + & Jha et al. (44) \\
\hline Human lymphocytes & Sodium Arsenite & $\mathrm{CA}$ & + & + & Wiencke and Yager (42) \\
\hline Human lymphocyte & Sodium Arsenite & SCE & + & + & Yager and Wiencke (43) \\
\hline Human lymphocyte & Sodium Arsenite & SCE & + & + & Hartmann and Speit (45) \\
\hline Human lymphocyte & Sodium Arsenite & $\mathrm{CA}$ & + & + & Vega et al. (29) \\
\hline Human fibroblasts & $\begin{array}{l}\text { Sodium Arsenite } \\
\text { and Sodium Arsenate }\end{array}$ & $\mathrm{CA}$ & + & + & Oya-Ohta et al. (33) \\
\hline Human lymphocytes & Sodium Arsenite & $\mathrm{CA}$ & + & + & Ramirez et al. (30) \\
\hline Human lymphocytes & $\begin{array}{l}\text { Sodium Arsenite } \\
\text { and Sodium Arsenate }\end{array}$ & SCE & + & + & Rasmussen and Menzel (46) \\
\hline Human lymphocytes & Sodium Arsenite & $\mathrm{MN}$ & + & + & Schaumloffel and Gebel (47) \\
\hline Human fibroblasts & Sodium Arsenite & $\mathrm{MN}$ & + & + & Yih and Lee (34) \\
\hline Human lymphocytes & Sodium Arsenate & DNA damage & + & + & Sordo et al. (50) \\
\hline TK6 human lymphoblastoid cells & $\begin{array}{l}\text { Sodium Arsenite } \\
\text { and Sodium Arsenate }\end{array}$ & DNA damage & + & + & Guillamet et al. (51) \\
\hline Human lymphocytes & $\begin{array}{l}\text { Sodium Arsenite } \\
\text { and Sodium Arsenate }\end{array}$ & $\mathrm{MN}$ & + & + & Colognato et al. (48) \\
\hline Human lymphocytes & Sodium Arsenite & SCE & + & + & Avani and Rao (49) \\
\hline $\begin{array}{l}\text { HL-60 (human promyelocytic } \\
\text { leukemia) cells }\end{array}$ & Sodium Arsenite & DNA damage & + & + & Yedjou and Tchounwou (52) \\
\hline $\begin{array}{l}\text { RKO (human colorectal } \\
\text { carcinoma) }\end{array}$ & Sodium Arsenite & $\mathrm{MN}$ & + & + & Salazar et al. (54) \\
\hline HT-29 (human colon cancer) cells & Sodium Arsenite & DNA damage & + & + & Stevens et al. (53) \\
\hline $\begin{array}{l}\text { Human lung adenocarcinoma } \\
\text { A549 cells }\end{array}$ & $\begin{array}{l}\text { Arsenic Trioxide } \\
\text { and Sodium Arsenite }\end{array}$ & $\begin{array}{l}\text { Chromosomal } \\
\text { breakage/MN }\end{array}$ & + & + & Jiang et al. (35) \\
\hline Human hepatocellular carcinoma & Sodium Arsenite & DNA damage & + & + & Alarifi et al. (55) \\
\hline Human hepatocyte L02 & $\begin{array}{l}\text { Sodium Arsenite } \\
\text { and Arsenic Trioxide }\end{array}$ & $\begin{array}{l}\text { Chromosomal } \\
\text { breakage/MN }\end{array}$ & + & + & Hu et al. (36) \\
\hline Human pluripotent stem cells & Arsenic Trioxide & DNA damage & + & + & Graham et al. (56) \\
\hline $\begin{array}{l}\text { Primary human bronchial } \\
\text { fibroblasts and normal primary } \\
\text { human bronchial epithelial cells }\end{array}$ & Sodium Arsenite & $\begin{array}{l}\text { CA and DNA } \\
\text { damage }\end{array}$ & + & + & Xie et al. (57) \\
\hline
\end{tabular}


nic in cultured human lymphocytes treated with sodium arsenite showed a dose-dependent increase in CA over concentrations ranging from 0.001 to $0.1 \mu \mathrm{M}$. Sodium arsenite-treated cells from various donors exhibited similar CA frequencies (30). They also investigated spindle formation using an anti- $\beta$-tubulin antibody which indicated that arsenite disrupts spindle formation by interacting with microtubules. Huang et al. (31), investigated the effects of treatment with arsenicals during two different stages of growth. Post-treatment with sodium arsenite in the logarithmic growth phase in human lymphocytes treated with methanesulfonate synergistically increased CA in a dose-dependent manner. However, sodium arsenite treatment in stationary phase had no apparent effect on the clastogenicity of ethyl methanesulfonate treatment, which indicated that sodium arsenite has significant genotoxic properties. In 1995, Huang et al. performed similar experiments on cultured human fibroblasts, which demonstrated an inhibitory effect of arsenic on enzyme activity and significant CA. CA increased with sodium arsenite treatment in a dose-dependent manner (32). Oya-Ohta et al. (33) observed clastogenic effects of different arsenic compounds on cultured human fibroblasts. Both arsenite and arsenate induced significant $\mathrm{CA}$ in cultured human fibroblasts. These authors also concluded that glutathione (GSH) plays an important role in protecting against genotoxic effects of inorganic arsenic. Yih and Lee (34) treated cultured human fibroblast cells with low dose arsenite for longer periods of time and high dose arsenite for shorter periods of time. In both cases, similar levels of arsenic accumulation were observed, but different levels of MN induction were observed. These results imply that oxidative stress induces micronuclei in human fibroblast cells. Jiang et al. (35) compared the in vitro effects of sodium arsenite and arsenic trioxide on human lung adenocarcinoma A549 cells and found that both arsenicals caused cytotoxicity, DNA damage, and chromosomal breakage as measured by MN assay. They observed that genotoxic effects were much higher in arsenic trioxide versus sodium arsenite treated cells and concluded that these differential effects were due to their differential mechanisms to induce genotoxicity and anticancer effects. Hu et al. (36) stated that both sodium arsenite and arsenic trioxide induced dose-dependent inhibition of colony formation, increased cellular apoptotic rate, increased reactive oxygen species levels, and increased MN frequency, with decreased cellular viability, colony formation rate, and GSH content in human hepatocyte L02 cells.

Several studies evaluated SCE to study genotoxicity of arsenic. Zanzoni and Jung (37) evaluated SCE in metaphase in normal human lymphocytes after treatment with inorganic trivalent arsenic. They found a significant dosedependent increase in SCE. Nordenson et al. (38) investigated SCE in cultured lymphocytes after exposure to triva- lent and pentavalent arsenic and observed that trivalent arsenic induced more significant SCE than pentavalent arsenic. Sodium arsenite induced a higher rate of SCE in Blackfoot disease patients consuming arsenic-contaminated water for more than fifteen years compared to healthy individuals drinking tap water (39). This sodium arsenite dose-dependent increase in SCE resulted in delayed cell growth of lymphocytes. Crossen (40) indicated that although arsenic induces SCE in human lymphocytes, dose-response to arsenic varies among individuals with regard to SCE. Sahu et al. (41) demonstrated a significant increase in the frequencies of SCE in sodium arsenite-treated lymphocytes. When arsenite treated lymphocytes were exposed to UV rays, the increase in SCE did not reflect an additive effect of the two agents. In another study, induction of SCE and CA were measured in normal human lymphocytes treated with low concentrations of arsenite alone and arsenite in combination with the DNA cross linking agent diepoxybutane (DEB) (42). Lymphocytes treated with arsenite concentrations as low as $1 \mu \mathrm{M}$ displayed increased SCE frequencies, while CA frequencies were increased at $2 \mu \mathrm{M}$ of arsenite. In the following year, Wiencke and Yager (43) again concluded that arsenite specifically potentiates CA formation induced by DEB, but does not affect induction of SCE. These studies suggest a specific interaction of arsenite with induction or repair of DNA damage produced by DEB that leads to CA but not to SCE. Jha et al. (44) performed a similar experiment in which human lymphocytes were treated with a combination of arsenite and $\mathrm{X}$-rays. They found a dose-dependent response to arsenite treatment alone, whereas treatment with arsenite in combination with X-rays produced a synergistic effect. Hartmann and Speit (45) compared the results of induction of SCE by arsenic on cultured human lymphocytes with DNA damage by single cell gel electrophoresis (comet assay). They found that arsenic concentrations that were toxic in the SCE test did not produce noticeable effects in the SCG assay, suggesting that the effects of arsenicals are not consistent for all genotoxicity assays. Rasmussen and Menzel (46) compared the genotoxic effects of arsenite in lymphoblastoid cell lines and cultured human lymphocytes from a group of normal healthy volunteers exposed to sodium arsenite for $40 \mathrm{hr}$. SCE induction by arsenite was dosedependent. Schaumloffel and Gebel (47) found inorganic arsenic to be a more potent inducer of micronuclei than antimony in cultured human lymphocytes. Colognato et al. (48) measured $\mathrm{MN}$ in cultured human lymphocytes challenged with trivalent and pentavalent arsenicals. They found that trivalent arsenicals showed more genotoxicity compared to pentavalent arsenicals. Avani and Rao (49) treated peripheral blood lymphocyte cultures with a range of arsenic doses. Arsenic-treated cultures showed dosedependent SCE. Interestingly, supplementation with vitamin A showed a remarkable protective effect against arse- 
nic induced genotoxicity, mainly due to decreased oxidative stress resulting from free radical scavenging.

Several studies have demonstrated arsenic-induced DNA damage in vitro. Sordo et al. (50) showed that sodium arsenite has cytotoxic effects by analyzing mitotic and replication indices in cultured blood lymphocytes, and demonstrated genotoxic effects by comet assay. They found organic arsenicals such as dimethylarsinic acid (DMA) and monomethylarsonic acid (MMA) had lesser DNA damaging properties than sodium arsenite. Guilamet et al.
(51) investigated possible DNA damage by three different inorganic and five different organic arsenic compounds in the TK6 human lymphoblastoid cell line using the alkaline comet assay. The results indicated that sodium arsenite was the only inorganic arsenic compound with genotoxic properties. Similarly, Yedjou and Tchounwou (52) investigated genotoxicity of arsenic trioxide on the human leukemia cell line HL60 using comet assay. The results showed a dose-dependent increase in DNA damage, as evidenced by significant increases in comet tail length, tail arm, and
(A)

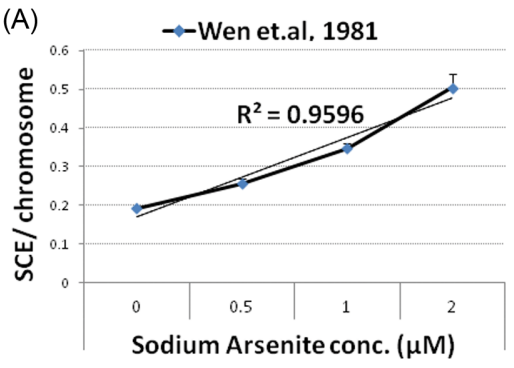

(D)

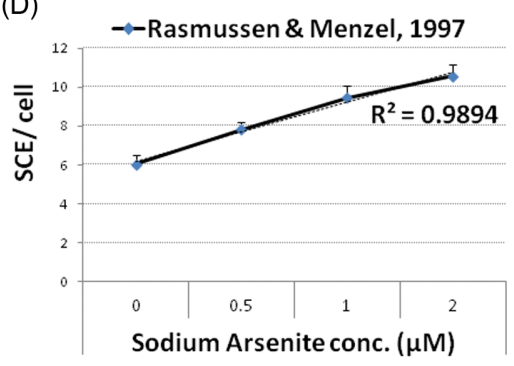

(G)

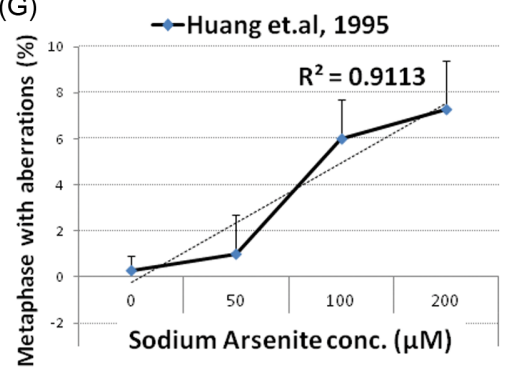

(J)

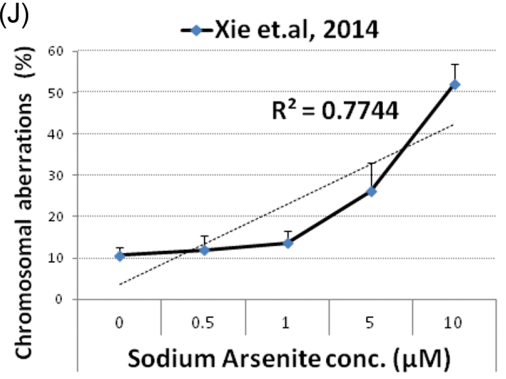

(B)

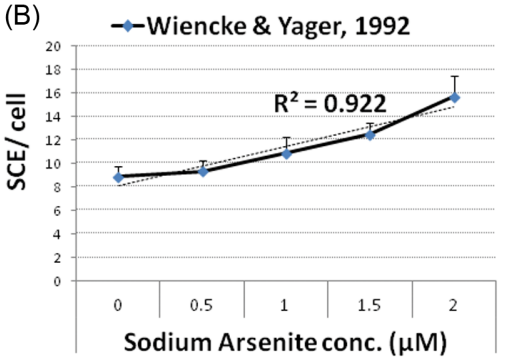

(E)

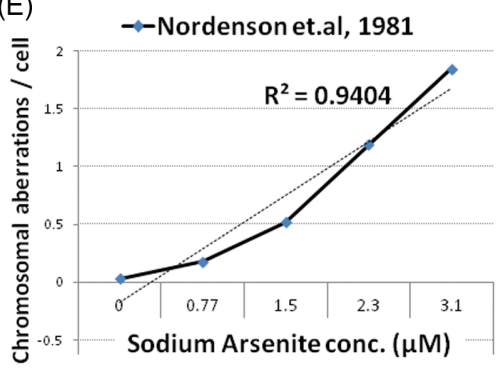

(H)

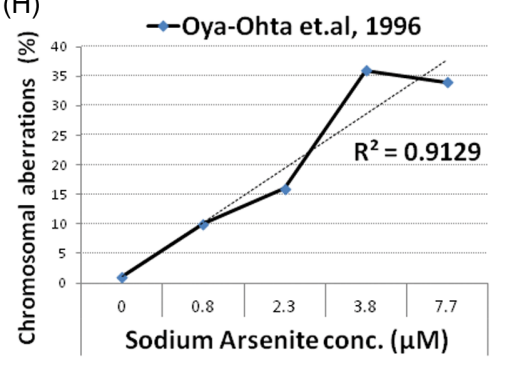

(K)

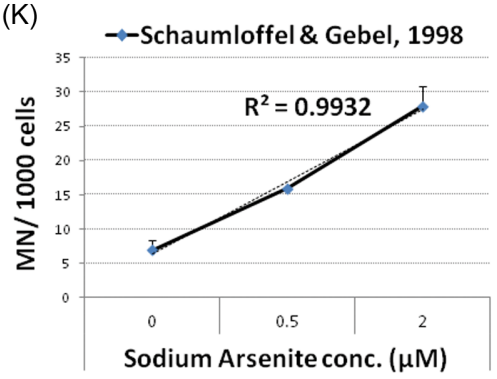

(C)

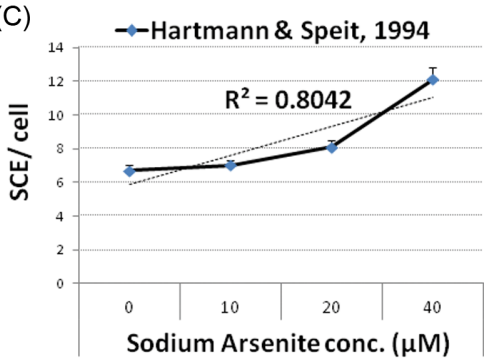

$(\mathrm{F})$
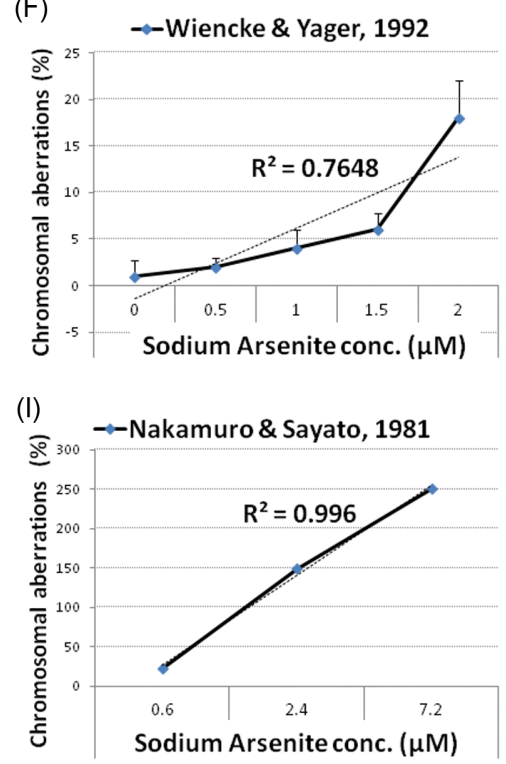

(L)

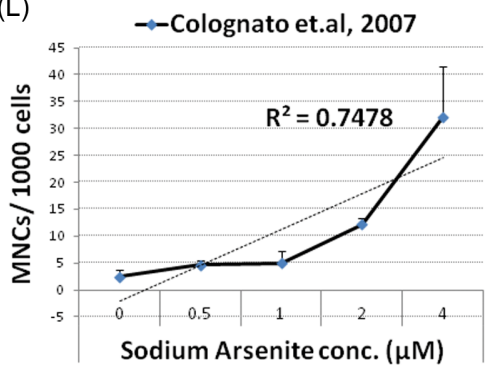

Fig. 1. In vitro dose dependent genotoxic effects of sodium arsenite as determined by (A) sister chromatid exchanges per chromosome, (B-D), sister chromatid exchanges per cell, (E) chromosomal aberrations per cell, (F-J) percentage of chromosomal aberrations, (K) frequency of micronuclei formation, and (L) frequency of micronucleated cells. Representative graphs are prepared based on data from various studies as indicated. Correlation between sodium arsenite concentrations and genetic damage was determined with a linear regression model. 
(A)

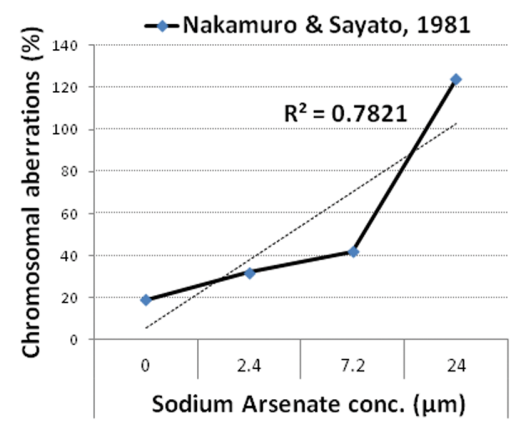

(B)

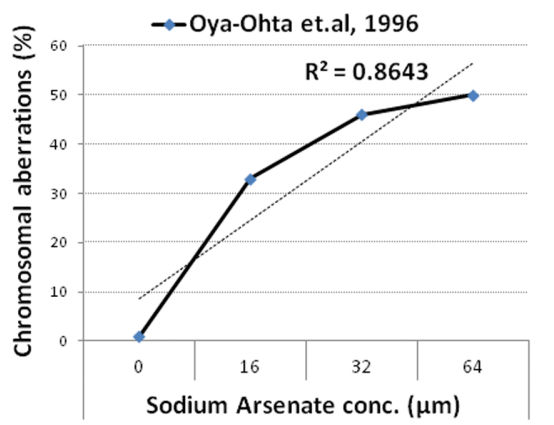

(C)

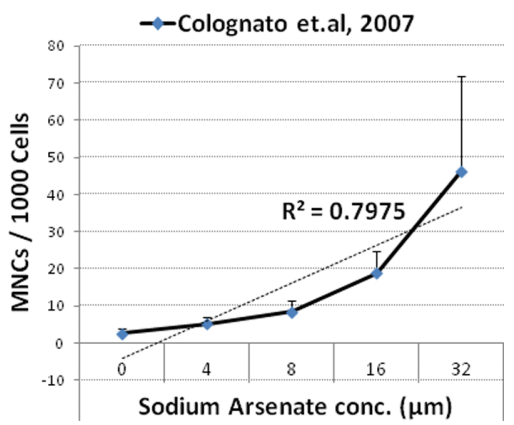

Fig. 2. In vitro dose dependent genotoxic effects of sodium arsenate as determined by (A, B) percentage of chromosomal aberrations and $(C)$ frequency of micronucleated cells. Representative graphs are prepared based on data from various studies as indicated. Correlation between sodium arsenate concentrations and genetic damage was determined with a linear regression model.

(A)

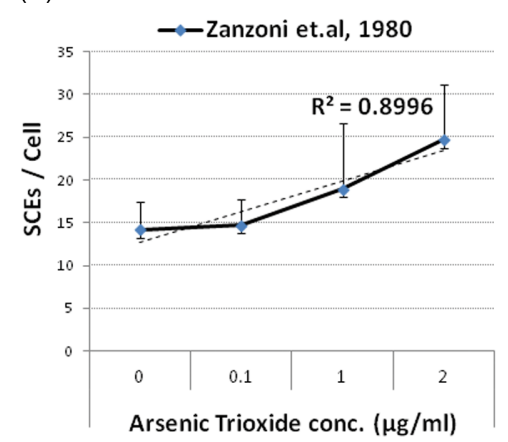

(B)

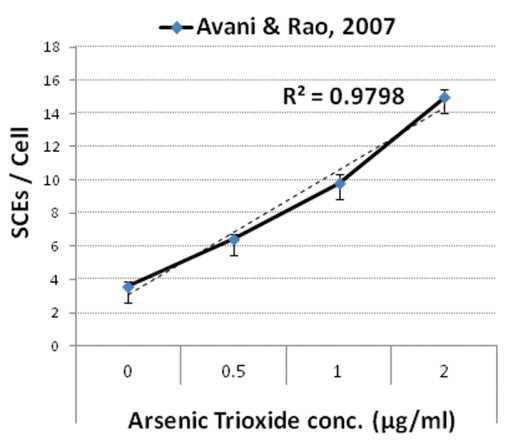

(C)

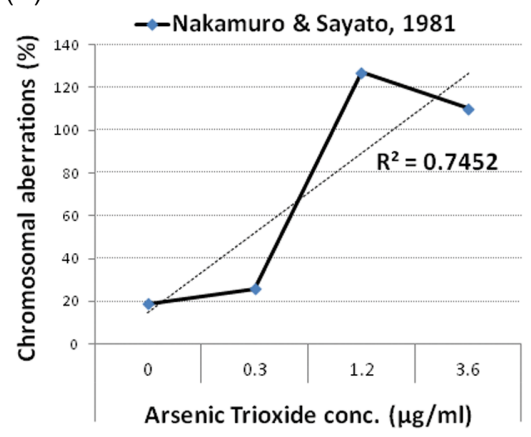

Fig. 3. In vitro dose dependent genotoxic effects of arsenic trioxide as determined by (A, B) sister chromatid exchanges per cell and (C) percentage of chromosomal aberrations. Representative graphs are prepared based on data from various studies as indicated. Correlation between arsenic trioxide concentrations and genetic damage was determined with a linear regression model.

tail moment. Stevens et al. (53) performed a similar experiment with human colon cancer cells. They observed a dose-related increase in DNA tail length in cells treated with arsenic trioxide when compared to non-exposed cells. Human colorectal carcinoma cells treated with sodium arsenite also presented with increased micronuclei frequency, demonstrating a genotoxic effect (54). Alarifi et al. (55) stated that human hepatocellular carcinoma cells treated with arsenic trioxide showed significant reduction in enzymes related to oxidative stress after 24 and $48 \mathrm{hr}$ of exposure. They also observed significant induction of DNA damage as measured by comet assay. Recently, Graham et al. (56) performed an experiment with human induced pluripotent cells (IPS) and demonstrated a dose-dependent decrease in cell viability and increase in tail length and moment, in addition to destruction of intact DNA when exposed to arsenic trioxide. Xie et al. (57) reported that human primary bronchial and epithelial cells in vitro exhibited a dose-dependent increase in genotoxicity as evidenced by chromosomal damage and DNA damage measured by Comet assay.

Figs. 1, 2 and 3 show analysis of dose-dependent geno- toxic effects induced by arsenic using various genotoxic endpoints. The data are summarized using coefficients of determination $\left(r^{2}\right)$. The $r^{2}$ values were calculated only from publications where full data were available. It is evident from Table 1 that, except for one publication, all studies demonstrated dose-dependent genotoxic effects induced by different species of inorganic arsenic. These results clearly indicate that inorganic arsenic is genotoxic in human cells in vitro.

\section{GENOTOXICITY STUDIES OF INORGANIC ARSENIC ON HUMAN CELLS IN VIVO}

Table 2 summarizes results of genotoxicity studies emphasizing $\mathrm{CA}, \mathrm{SCE}$, and $\mathrm{MN}$ performed in human populations. Few studies have measured DNA damage as a genotoxic parameter upon exposure to arsenic. Most of the studies summarized focused on human populations exposed to arsenic through drinking water. Ground water arsenic mainly contains the inorganic trivalent and pentavalent arsenic, with minor amounts of organic arsenic. As such, we considered reports of genotoxic effects in these studies 
Table 2. Inorganic arsenic induced genotoxic effects on human cells in vivo

\begin{tabular}{|c|c|c|c|c|c|}
\hline Test systems & Arsenic species & End points & Effects & $\begin{array}{l}\text { Dose } \\
\text { response }\end{array}$ & References \\
\hline Human lymphocytes & Arsenic in drinking water & $\mathrm{CA}$ & + & $\mathrm{N} / \mathrm{A}$ & Petres et al. (58) \\
\hline Human lymphocytes & Arsenic in drinking water & $\mathrm{CA}$ & + & N/A & Beckman et al. (63) \\
\hline Human lymphocytes & Arsenic in drinking water & SCE & + & N/A & Burgdorf et al. (60) \\
\hline Human lymphocytes & $\begin{array}{l}\text { Industrial exposure of Sodium } \\
\text { Arsenite, Sodium Arsenate } \\
\text { from Ronnskar smelter }\end{array}$ & $\mathrm{CA}$ & + & N/A & Nordenson et al. $(59,64)$ \\
\hline Human lymphocytes & $\begin{array}{l}\text { Psotriatric patients treated } \\
\text { with Sodium Arsenite }\end{array}$ & SCE & + & N/A & Wen et al. (39) \\
\hline Human lymphocytes & Arsenic in drinking water & SCE, CA & - & N/A & Vig et al. (62) \\
\hline Human lymphocytes & Arsenic in drinking water & $\mathrm{CA}, \mathrm{MN}$ & + & N/A & $\mathrm{Hu}(65)$ \\
\hline Human lymphocytes & Arsenic in drinking water & $\mathrm{CA}$ & - & N/A & Ostrosky-Wegman et al. (61) \\
\hline Human lymphocytes & Arsenic in drinking water & $\mathrm{MN}$ & + & N/A & Nilsson et al. (66) \\
\hline Human lymphocytes & Arsenic in drinking water & SCE & + & N/A & Lerda (67) \\
\hline Human lymphocytes & Arsenic in drinking water & $\mathrm{MN}$ & + & N/A & Warner et al. (68) \\
\hline Human lymphocytes & Arsenic in drinking water & SCE, MN & + & N/A & Dulout et al. (69) \\
\hline Human urothelial cells & Arsenic in drinking water & $\mathrm{MN}$ & + & $\mathrm{N} / \mathrm{A},+$ & Moore et al. $(70,71)$ \\
\hline Human urothelial cells & Arsenic in drinking water & $\mathrm{MN}$ & & N/A & Biggs et al. (72) \\
\hline Human lymphocytes & Arsenic in drinking water & $\mathrm{CA}, \mathrm{MN}$ & + & N/A & Gonsebatt et al. (73) \\
\hline Human urothelial cells & Arsenic in drinking water & $\mathrm{CA}$ & + & N/A & Mäki-Paakkanen et al. (74) \\
\hline Human urothelial cells & Arsenic in drinking water & $\mathrm{CA}$ & - & N/A & Liou et al. (9) \\
\hline $\begin{array}{l}\text { Human Buccal mucosal cells, } \\
\text { epithelial cells in sputum, } \\
\text { and urothelial cells }\end{array}$ & Arsenic in drinking water & $\mathrm{MN}$ & + & N/A & Tian et al. (25) \\
\hline $\begin{array}{l}\text { Buccal mucosa, urothelial } \\
\text { cells and Lymphocytes }\end{array}$ & Arsenic in drinking water & $\mathrm{MN}$ & + & N/A & Basu et al. $(14,79)$ \\
\hline Human in lymphocytes & Arsenic in drinking water & DNA Damage & + & + & Basu et al. (80) \\
\hline Human lymphocytes & Arsenic in drinking water & CA and SCE & + & $\mathrm{N} / \mathrm{A}$ & Mahata et al. (78) \\
\hline Human lymphocytes from children & Arsenic in drinking water & DNA damage & + & N/A & Yanez et al. (81) \\
\hline Human lymphocytes & Arsenic in drinking water & MN & + & N/A & Martínez et al. (75) \\
\hline Human buccal mucosa cells & Arsenic in drinking water & $\mathrm{MN}$ & + & N/A & Martínez et al. (76) \\
\hline $\begin{array}{l}\text { Human lymphocytes, buccal } \\
\text { mucosa }\end{array}$ & Arsenic in drinking water & $\mathrm{CA}, \mathrm{MN}$ & + & N/A & Ghosh et al. $(2,3)$ \\
\hline Human lymphocytes & Arsenic in drinking water & $\mathrm{MN}$ & + & N/A & Paiva et al. (82) \\
\hline Human urothelial cells & Arsenic in drinking water & $\mathrm{MN}$ & + & + & Banerjee et al. (7) \\
\hline Human lymphocytes & Arsenic in drinking water & $\begin{array}{l}\text { MN and DNA } \\
\text { damage }\end{array}$ & + & N/A & Sampayo-Reyes et al. (77) \\
\hline Human lymphocytes & Arsenic in drinking water & $\mathrm{CA}$ & + & N/A & Dastgiri et al. (83) \\
\hline Buccal mucosa cells from human & Arsenic in drinking water & $\mathrm{MN}$ & + & N/A & Bartolotta et al. (84) \\
\hline $\begin{array}{l}\text { Human urothelial cells from } \\
\text { children }\end{array}$ & Inorganic Arsenic from soil & $\mathrm{MN}$ & + & N/A & Gamiño-Gutiérrez et al. (85) \\
\hline Human urothelial cells & Arsenic in drinking water & $\mathrm{MN}$ & + & N/A & Paul et al. (21) \\
\hline $\begin{array}{l}\text { Buccal mucosa, urothelial } \\
\text { cells and Lymphocytes }\end{array}$ & Arsenic in drinking water & MN & + & N/A & Chatterjee et al. (86) \\
\hline
\end{tabular}


to be mainly from inorganic arsenic sources such as arsenate and arsenite. Petres et al. (58) analyzed CA in lymphocytes of a population exposed to arsenic through drinking water. They found an increased number of chromosome and chromatid structural anomalies, as well as increased aneuploidy rate, in the arsenic-exposed group. Nordenson et al. (59) found increased frequency of CA in lymphocytes of psoriatic patients who were treated with arsenic, even more than 15 years after discontinuing therapy. Burgdorf et al. (60) reported an increased SCE rate in lymphocytes of patients treated with arsenic in the form of potassium arsenite, indicating significant genotoxic potential of this arsenical. A pilot study on hydroarsenicism was carried out by Ostrosky Wegman et al. (61) on an arsenicexposed population in Mexico. The frequency of SCE and percentage of CA were similar in chronically exposed individuals and individuals who were less-exposed to arsenic. However complex aberrations were more frequent in the chronically exposed group. In another study, conducted by Vig et al. (62) on humans of different ages and backgrounds who had been drinking contaminated water with more than $0.05 \mathrm{mg} / \mathrm{L}(0.05 \mathrm{ppm})$ arsenic for a minimum period of five years, no correlation was found between frequency of CA and SCE in lymphocytes and amount of arsenic in the water.

Copper smelters are potential sources of high arsenic pollution and many studies have been conducted among different copper smelters around the world. In the study conducted by Beckman et al. (63) the occurrence of CAs in lymphocytes significantly increased among the smelter workers compared to control. Nordenson et al. (64) found a significant interaction of smoking with arsenic exposure suggesting smoking can influence the genotoxic outcome of arsenic exposure. Another study conducted on smelter workers of Yunnan Tin Corporation in China found increased $\mathrm{CA}$ and $\mathrm{MN}$ frequency in cultured lymphocytes of arsenic-exposed participants, which was also associated with occurrence of lung cancer (65). In another study by Nilsson et al. (66) a significantly higher incidence of CA was found in hair and nail tissues in five women residing in an area heavily contaminated with inorganic arsenic from a copper smelter located in Bulgaria compared to controls. In Argentina, individuals who had been drinking arsenic-contaminated water (more than $0.13 \mathrm{mg} / \mathrm{L}$ ) for a period not less than 20 years had significantly increased SCE compared to control (67). A study in Nevada by Warner et al. (68) stated that a distinct 1.8-fold increase with $90 \%$ confidence interval (1.06-2.99-fold) was observed in frequency of $\mathrm{MN}$ in bladder cells in the exposed group when compared with the unexposed group. They also stated that $\mathrm{MN}$ frequency in bladder cells was positively related to concentration of inorganic arsenic in urine. Dulout et al. (69) studied the clastogenicity and aneugenicity of arsenic in women and children only. The popula- tion residing in Northwestern Argentina was exposed to high levels of arsenic (approximately $0.2 \mathrm{mg} / \mathrm{L}$ in drinking water. A similar ethnic group was evaluated with extremely low exposure to arsenic via drinking water from Rosario de Lerma, Salta. Genotoxic effects were evaluated by MN assay in binucleated cells and SCE in lymphocytes. This study found a significant increase in frequency of $\mathrm{MN}$, but no specific change in SCE of the exposed group. Moore et al. (70) found elevated occurrence of $\mathrm{MN}$ in exfoliated bladder cells in individuals chronically exposed to high levels of arsenic in Nevada when compared with matched controls. Frequencies of MN contain acentric fragments which results from chromosome breakage. In another crosssectional biomarker study in a Chilean male population chronically exposed to arsenic (average concentration was $600 \mu \mathrm{g} / \mathrm{L}$ ), the same research group observed elevated $\mathrm{MN}$ frequencies in bladder cells when compared to the low arsenic exposure (average concentration was $15 \mu \mathrm{g} / \mathrm{L}$ ) group (71). MN was detected by fluorescence in situ hybridization with a centromeric probe to detect the presence of whole chromosomes. They observed a dosedependent increase in $\mathrm{MN}$ with urine arsenic levels. The authors concluded that arsenic can induce genetic damage and that chromosome breakage is the main cause of $\mathrm{MN}$ formation (71). Biggs et al. (72) used the MN assay to evaluate exfoliated bladder cells of individuals exposed to arsenic through drinking water. They reported that bladder cell micronuclei correlated with arsenic exposure.

In Mexico, Gonsebatt et al. (73) studied CA in blood lymphocytes and $\mathrm{MN}$ in epithelial cells obtained from oral mucosa and urine samples. A significant increase in frequency of $\mathrm{MN}$ in oral and urinary epithelial cells and chromatid and isochromatid deletions in lymphocytes were found in the arsenic-exposed group. They also found that individuals with skin lesions had more $\mathrm{MN}$ in oral cells. Mäki-Paakkanen et al. (74) observed a significant increase in CA in lymphocytes of 42 individuals exposed to arsenic through well water with an arsenic concentration of $410 \mu \mathrm{g} / \mathrm{L}$ in Finland. Blackfoot disease is well-known for its association with consumption of arsenic containing well water. In a cytogenetic survey conducted by Liou et al. (9) on 686 residents of three villages in a Blackfoot endemic area in Taiwan, 31 patients developed cancer during the 4 year follow up period. Twenty-two patients in the group that did not develop cancer were selected as controls, and 22 patients that developed cancer were selected as exposed group. The frequencies of chromosome-type aberrations were significantly higher in the exposed group than that of the control. There was no significant difference in SCE and chromatid type aberrations among the exposed and control groups. Other than CA and SCE, many studies have been performed to evaluate micronuclei formation in urothelial, buccal, or peripheral lymphocyte cells in all parts of the world. Tian et al. (25) 
observed a significant increase in MN in buccal cells, bladder cells, and sputum cells of individuals exposed to high arsenic levels compared to those with low exposure from a population in Central West Inner Mongolia, China. Martínez et al. (75) studied MN in human lymphocytes of individuals exposed to arsenic through drinking water and observed that the frequency of $\mathrm{MN}$ in the exposed group was significantly higher compared to the control group. In contrast, Martínez et al. (76) found no association between frequency of $\mathrm{MN}$ in buccal cells and arsenic levels in drinking water. Ghosh et al. (2) stated that higher levels of $\mathrm{MN}$ in oral mucosa and CA in lymphocytes were found in an arsenic exposed population. In the following year, Ghosh et al. (11) showed greater levels of CA in lymphocytes of individuals with neoplastic skin diseases versus non-cancerous skin lesions in a population exposed to arsenic in well water. Sampayo Reyes et al. (77) found a positive association in micronuclei and percentage of DNA damage evidenced by tail length using comet assay of urinary bladder cells and lymphocytes.

In West Bengal, India, arsenic is an epidemic in nine districts. In addition, Bangladesh is also associated with high levels of various clinical manifestations of chronic arsenicosis. Many studies have been conducted in arsenic contaminated areas of West Bengal. Mahata et al. (78) conducted a bio-monitoring study using $\mathrm{CA}$ and $\mathrm{SCE}$ as end points to investigate the cytogenetic effects of chronic arsenic exposure in a population of 59 individuals residing in North 24 Parganas district. A significant increase in both CA and SCE were observed in the exposed group when compared to the control group. Basu et al. (79) performed a similar experiment with a population from four affected districts of West Bengal, and found a statistically significant increase in frequency of $\mathrm{MN}$ in urothelial cells, oral mucosa, and lymphocytes when compared with controls. Two years later, Basu et al. (14) again performed a biomarker study on 163 inhabitants of North 24 Parganas and compared them with 154 unexposed controls residing in the unaffected East Midnapur. They found significantly elevated levels of micronuclei frequencies in the exposed group: 5.33 -fold versus control for lymphocytes, 4.63-fold for oral mucosa cells, and 4.71-fold for urothelial cells $p<0.01$ ). In the next year, the same group (80) used alkaline comet assay to measure DNA damage in lymphocytes of 30 people exposed to high levels of arsenic in drinking water. The exposed individuals expressed a significant dose-dependent increase in DNA damage $(p<0.01)$ in lymphocytes versus unexposed individuals.

Yanez et al. (81) studied DNA damage by comet assay in lymphocytes of children lymphocytes Villa de la Paz, S.L.P. (Mexico), with control samples taken from children living in a less exposed town (Matehuala). The urinary concentration of arsenic in children of Villa de la Paz (geometric mean $136 \mu \mathrm{g} / \mathrm{g}$ creatinine) was significantly higher than in the control children living in Matehuala ( $34 \mu \mathrm{g} / \mathrm{g}$ creatinine). The results found by the comet assay showed that the tail length and the tail moment in the exposed children were significantly higher than those observed for control $(p<0.05)$. In a study in Northern Chile, the relationship between arsenic occupational exposure and genotoxic effects in smelting plant workers was studied by Paiva et al. (82). They did not find any significant differences in MN in lymphocytes of the occupationally-exposed population. The effect of chronic exposure of arsenic on occurrence of dermatological symptoms was investigated by Dastgiri et al. (83) in a community in northwest Iran. The exposed group was from Ghopuz village $(1,031 \pm 1,103 \mu \mathrm{g} / \mathrm{L}$ of arsenic in drinking water $)$ and the control from a Mayan village with no arsenic exposure. Hyperkeratosis observed in the exposed group was 34 times higher than that of the control subjects. They also found that $25 \%$ of the exposed group showed CA ( $p=$ 0.05). Bartolotta et al. (84) evaluated micronuclei in exfoliated buccal cells of an arsenic-exposed group sampled from the rural population of Santiago del Estero and a control group consisting the urban population of Buenos Aires in Argentina. They found a significant $(p=0.0005)$ increase in number of micronuclei in the exposed group when compared to the control group. Banerjee et al. (7) reported that arsenic from rice alone can induced genotoxicity in humans when water arsenic content was less than the permissible limit set by WHO. A significant increase in $\mathrm{MN}$ was observed in urothelial cells of individuals who consume rice as a staple when the rice contained arsenic at a concentration of more than $200 \mu \mathrm{g} / \mathrm{kg}$ of rice. They also observed a dose-related increase in MN with rice arsenic concentrations. Gamino-Guitarrez et al. (85) carried out geochemical and health studies of children in urban areas of Villa de la Paz, S.L.P. (Mexico), where the surface has been contaminated with arsenic by mining activities for more than 200 years. They found that at least $20 \sim 30 \%$ of children had urine arsenic levels higher than the maximum intervention values set nationally and internationally. MN assay in exfoliated bladder cells was significantly higher in children with high urine arsenic levels. Chatterjee at al. (86) measured the frequency of $\mathrm{MN}$ in buccal mucosa, urothelial cells, and lymphocytes of children exposed to arsenic and compared it with buccal mucosa, urothelial, and lymphocyte cells of children from an unexposed area. They found all three cell types had significantly higher $(p<0.0001) \mathrm{MN}$ frequency in the arsenic exposed group compared to the unexposed group.

Fig. 4 shows the analysis of dose-response effects by evaluating the $r^{2}$ value from the data presented by the authors. Although almost all publications showed genotoxic effects of inorganic arsenic in vivo, only some authors have presented positive dose-response effects. As expected 
(A)

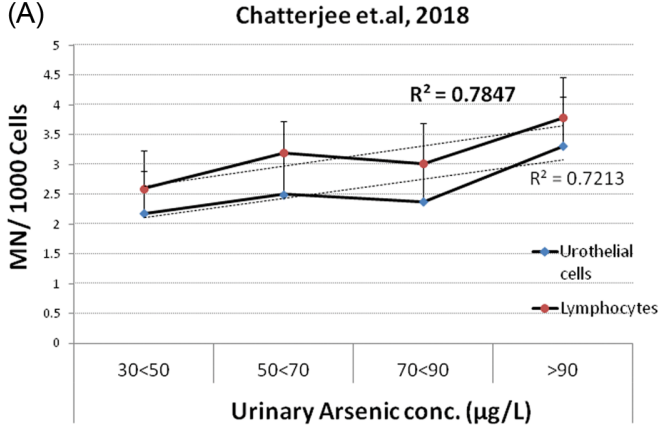

(C)

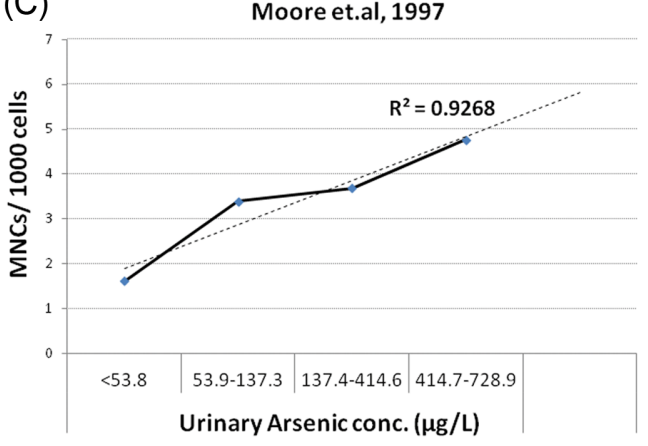

(B)

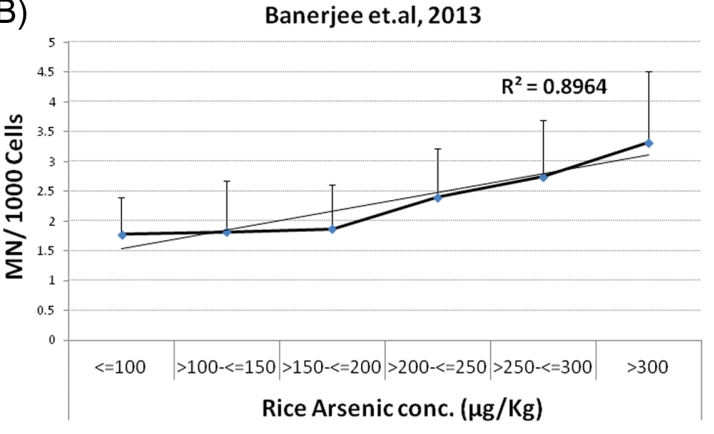

(D)

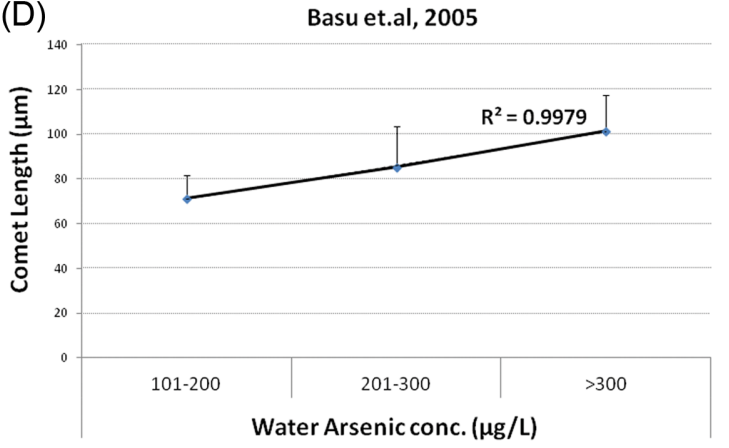

Fig. 4. In vivo dose dependent genotoxic effects of arsenic in humans exposed through various sources. Genotoxicity was estimated by (A, B) frequency of micronuclei formation, (C) frequency of micronucleated cells, and (D) comet length. Representative graphs are based on data from various studies as indicated. Correlation between arsenic concentrations and genetic damage was determined with a linear regression model.

in the in vivo studies in humans, it is difficult to obtain dose-response effects. Although arsenic exposure through drinking water is the same, there are several reasons for not reporting dose-response effects, such as: a) variation in consumption of arsenic contaminated water by different individuals, b) dietary habits of the individuals, c) variation in the rate of arsenic excretion and d) age, tobacco use, alcohol consumption, malnutrition, etc. All of these factors may contribute to genotoxic effects in vivo and thus, most in vivo studies do not show any dose-response effects even if they were divided into different groups based on water or urine arsenic levels. However, it is important to note that almost all in vivo studies on humans showed positive genotoxic effects when compared to arsenic unexposed population.

\section{CONCLUSIONS}

As per OECD guidelines, it is mandatory to include one in vitro test and one in vivo mammalian test to identify the genotoxic potential of the compound. If the compound shows genotoxic potential in vitro as measured by $\mathrm{CA}$, $\mathrm{MN}$, and DNA damage with evidence of dose-response effects and also genotoxic effects in vivo in a mammalian system, then, per OECD guidelines, we can consider that compound as a genotoxic agent. Interestingly inorganic arsenic demonstrates clear genotoxic effects on human cells in vitro with evidence of dose-response effects as described in this review. Similarly, almost all in vivo studies on inorganic arsenic also clearly show genotoxic effects in human systems. Since all in vivo results were obtained from human studies, the results may not show dose-response effects, an issue which have addressed in the text. Considering substantial global publications on genotoxic potential of inorganic arsenic on human cells in vitro and in vivo, we have no hesitation to conclude that inorganic arsenic is a genotoxic human carcinogen and not a non-genotoxic carcinogen.

\section{ACKNOWLEDGMENTS}

Authors are grateful to Indian National Science Academy, New Delhi 1100002, for the award of the INSA Senior Scientist position to Dr. Ashok K. Giri.

\section{CONFLICT OF INTEREST}

The authors declare they have no actual or potential competing financial interests.

Received August 12, 2018; Revised August 24, 2018; Accepted September 7, 2018 


\section{REFERENCES}

1. Polya, D. and Charlet, L. (2009) Environmental science: rising arsenic risk? Nat. Geosci., 2, 383-384.

2. Ghosh, P., Basu, A., Mahata, J., Basu, S., Sengupta, M., Das, J.K., Mukherjee, A., Sarkar, A.K., Mondal, L., Ray, K. and Giri, A.K. (2006) Cytogenetic damage and genetic variants in the individuals susceptible to arsenic-induced cancer through drinking water. Int. J. Cancer, 118, 2470-2478.

3. Ghosh, P., Banerjee, M., De Chaudhuri, S., Chowdhury, R., Das, J.K., Mukherjee, A., Sarkar, A.K., Mondal, L., Baidya, K., Sau, T.J., Banerjee, A., Basu, A., Chaudhuri, K., Ray, K. and Giri, A.K. (2007) Comparison of health effects between individuals with and without skin lesions in the population exposed to arsenic through drinking water in West Bengal, India. J. Expo. Sci. Environ. Epidemiol., 17, 215-223.

4. Reichard, J.F., Schnekenburger, M. and Puga, A. (2007) Long term low-dose arsenic exposure induces loss of DNA methylation. Biochem. Biophys. Res. Commun., 352, 188192.

5. Coppin, J.F., Qu, W. and Waalkes, M.P. (2008) Interplay between cellular methyl metabolism and adaptive efflux during oncogenic transformation from chronic arsenic exposure in human cells. J. Biol. Chem., 283, 19342-19350.

6. Noma, K.I., Allis, C.D. and Grewal, S.I. (2001) Transitions in distinct histone $\mathrm{H} 3$ methylation patterns at the heterochromatin domain boundaries. Science, 293, 1150-1155.

7. Banerjee, M., Banerjee, N., Bhattacharjee, P., Mondal, D., Lythgoe, P.R., Martínez, M., Pan, J., Polya, D.A. and Giri, A.K. (2013) High arsenic in rice is associated with elevated genotoxic effects in humans. Sci. Rep., 3, 2195.

8. Paul, S., Banerjee, N., Chatterjee, A., Sau, T.J., Das, J.K., Mishra, P.K., Chakrabarti, P., Bandyopadhyay, A. and Giri, A.K. (2014) Arsenic-induced promoter hypomethylation and over-expression of ERCC2 reduces DNA repair capacity in humans by non-disjunction of the ERCC2-Cdk7 complex. Metallomics, 6, 864-873.

9. Liou, S.H., Lung, J.C., Chen, Y.H., Yang, T., Hsieh, L.L., Chen, C.J. and Wu, T.N. (1999) Increased chromosome-type chromosome aberration frequencies as biomarkers of cancer risk in a blackfoot endemic area. Cancer Res., 59, 14811484.

10. Rossner, P., Boffetta, P., Ceppi, M., Bonassi, S., Smerhovsky, Z., Landa, K., Juzova, D. and Šrám, R.J. (2005) Chromosomal aberrations in lymphocytes of healthy subjects and risk of cancer. Environ. Health Perspect., 113, 517.

11. Ghosh, P., Banerjee, M., De Chaudhuri, S., Das, J.K., Sarma, N., Basu, A. and Giri, A.K. (2007) Increased chromosome aberration frequencies in the Bowen's patients compared to non-cancerous skin lesions individuals exposed to arsenic. Mutat. Res., 632, 104-110.

12. Yamanaka, K., Hoshino, M., Okamoto, M., Sawamura, R., Hasegawa, A. and Okada, S. (1990) Induction of DNA damage by dimethylarsine, a metabolite of inorganic arsenics, is for the major part likely due to its peroxyl radical. Biochem. Biophys. Res. Commun., 168, 58-64.

13. Ghosh, P., Basu, A., Singh, K.K. and Giri, A.K. (2008) Evaluation of cell types for assessment of cytogenetic damage in arsenic exposed population. Mol. Cancer., 7, 45.
14. Basu, A., Ghosh, P., Das, J.K., Banerjee, A., Ray, K. and Giri, A.K. (2004) Micronuclei as biomarkers of carcinogen exposure in populations exposed to arsenic through drinking water in West Bengal, India: a comparative study in three cell types. Cancer Epidemiol. Biomarkers Prev., 13, 820827.

15. Smith, A.H., Hopenhayn-Rich, C., Warner, M., Biggs, M.L., Moore, L. and Smith, M.T. (1993) Rationale for selecting exfoliated bladder cell micronuclei as potential biomarkers for arsenic genotoxicity. J. Toxicol. Environ. Health, 40, 223-234.

16. Cohen, S.M., Chowdhury, A. and Arlond, L.L. (2016) Inorganic arsenic: a non genotoxic carcinogen. J. Environ. Sci. (China), 49, 28-37.

17. Kligerman, A. (2013) Arsenic Is A Genotoxic Carcinogen. Env. Mutagenesis Geneomics Society Meeting (2013 Sep 21-25), Monterey, CA.

18. Hei, T.K., Liu, S.X. and Waldren, C. (1998) Mutagenicity of arsenic in mammalian cells: role of reactive oxygen species. Proc. Natl. Acad. Sci. U.S.A., 95, 8103-8107.

19. Marchiset-Ferlay, N., Savanovitch, C. and Sauvant-Rochat, M.P. (2012) What is the best biomarker to assess arsenic exposure via drinking water? Environ. Int., 39, 150-171.

20. Faita, F., Cori, L., Bianchi, F. and Andreassi, M.G. (2013) Arsenic-induced genotoxicity and genetic susceptibility to arsenic-related pathologies. Int. J. Environ. Res. Public Health, 10, 1527-1546.

21. Paul, S., Bhattacharjee, P., Mishra, P.K., Chatterjee, D., Biswas, A., Deb, D., Ghosh, A., Mazumder, D.G. and Giri, A.K. (2013) Human urothelial micronucleus assay to assess genotoxic recovery by reduction of arsenic in drinking water: a cohort study in West Bengal, India. Biometals, 26, 855-862.

22. Mo, J., Xia, Y., Wade, T.J., Schmitt, M., Le, X.C., Dang, R. and Mumford, J.L. (2006) Chronic arsenic exposure and oxidative stress: OGG1 expression and arsenic exposure, nail seleniumand skin hyperkeratosis in Inner Mongolia. Environ. Health Perspect., 114, 835-841.

23. Bach, J., Peremartí, J., Annangi, B., Marcos, R. and Hernández, A. (2015) Reduced cellular DNA repair capacity after environmentally relevant arsenic exposure. Influence of Ogg1 deficiency. Mutat. Res., 779, 144-151.

24. Moore, M.M., Harrington-Brock, K. and Doerr, C.L. (1997) Relative genotoxic potency of arsenic and its methylated metabolites. Mutat. Res., 386, 279-290.

25. Tian, D., Ma, H., Feng, Z., Xia, Y., Le, X.C., Ni, Z., Allen, J., Collins, B., Schreinemachers, D. and Mumford, J.L. (2001) Analyses of micronuclei in exfoliated epithelial cells from individuals chronically exposed to arsenic via drinking water in inner Mongolia, China. J. Toxicol. Environ. Health Part A, 64, 473-484.

26. Sun, H.J., Rathinasabapathi, B., Wu, B., Luo, J., Pu, L.P. and Ma, L.Q. (2014) Arsenic and selenium toxicity and their interactive effects in humans. Environ. Int., 69, 148-158.

27. Petres, J., Baron, D. and Hagedorn, M. (1977) Effects of arsenic cell metabolism and cell proliferation: cytogenetic and biochemical studies. Environ. Health Perspect., 19, 223227.

28. Nakamuro, K. and Sayato, Y. (1981) Comparative studies of 
chromosomal aberration induced by trivalent and pentavalent arsenic. Mutat. Res., 88, 73-80.

29. Vega, L., Gonsebatt, M.E. and Ostrosky-Wegman, P. (1995) Aneugenic effect of sodium arsenite on human lymphocytes in vitro: an individual susceptibility effect detected. Mutat. Res., 334, 365-373.

30. Ramirez, P., Eastmond, D.A., Laclette, J.P. and OstroskyWegman, P. (1997) Disruption of microtubule assembly and spindle formation as a mechanism for the induction of aneuploid cells by sodium arsenite and vanadium pentoxide. Mutat. Res., 386, 291-298.

31. Huang, R.Y., Jan, K.Y. and Lee, T.C. (1987) Posttreatment with sodium arsenite is coclastogenic in log phase but not in stationary phase. Hum. Genet., 75, 159-162.

32. Huang, R.N., Ho, I.C., Yih, L.H. and Lee, T.C. (1995) Sodium arsenite induces chromosome endoreduplication and inhibits protein phosphatase activity in human fibroblasts. Environ. Mol. Mutagen., 25, 188-196.

33. Oya-Ohta, Y., Kaise, T. and Ochi, T. (1996) Induction of chromosomal aberrations in cultured human fibroblasts by inorganic and organic arsenic compounds and the different roles of glutathione in such induction. Mutat. Res., 357, 123129.

34. Yih, L.H. and Lee, T.C. (1999) Effects of exposure protocols on induction of kinetochore-plus and-minus micronuclei by arsenite in diploid human fibroblasts. Mutat. Res., 440, 75-82.

35. Jiang, X., Chen, C., Zhao, W. and Zhang, Z. (2013) Sodium arsenite and arsenic trioxide differently affect the oxidative stress, genotoxicity and apoptosis in A549 cells: an implication for the paradoxical mechanism. Environ. Toxicol. Pharmacol., 36, 891-902.

36. Hu, Y., Zhao, W., Chen, C., Jiang, X. and Zhang, Z. (2014) Research on the sodium arsenite and arsenic trioxide induced proliferation and apoptosis effects on human hepatocyte. Wei Sheng Yan Jiu, 43, 203-209.

37. Zanzoni, F. and Jung, E.G. (1980) Arsenic elevates the sister chromatid exchange (SCE) rate in human lymphocytes in vitro. Arch. Dermatol. Res., 267, 91-95.

38. Nordenson, I., Sweins, A. and Beckman, L. (1981) Chromosome aberrations in cultured human lymphocytes exposed to trivalent and pentavalent arsenic. Scand. J. Work Environ. Health, 7, 277-281.

39. Wen, W.N., Lieu, T.L., Chang, H.J., Wuu, S.W., Yau, M.L. and Jan, K.Y. (1981) Baseline and sodium arsenite-induced sister chromatid exchanges in cultured lymphocytes from patients with Blackfoot disease and healthy persons. Hum. Genet., 59, 201-203.

40. Crossen, P.E. (1983) Arsenic and SCE in human lymphocytes. Mutat. Res., 119, 415-419.

41. Sahu, R.K., Katsifis, S.P., Kinney, P.L. and Christie, N.T. (1989) Effects of nickel sulfate, lead sulfateand sodium arsenite alone and with UV light on sister chromatid exchanges in cultured human lymphocytes. Mol. Toxicol., 2, 129-136.

42. Wiencke, J.K. and Yager, J.W. (1992) Specificity of arsenite in potentiating cytogenetic damage induced by the DNA crosslinking agent diepoxybutane. Environ. Mol. Mutagen., 19, 195-200

43. Yager, J.W. and Wiencke, J.K. (1993) Enhancement of chro- mosomal damage by arsenic: implications for mechanism. Environ. Health Perspect., 101, 79-82.

44. Jha, A.N., Noditi, M., Nilsson, R. and Natarajan, A.T. (1992) Genotoxic effects of sodium arsenite on human cells. Mutat. Res., 284, 215-221.

45. Hartmann, A. and Speit, G. (1994) Comparative investigations of the genotoxic effects of metals in the single cell gel (SCG) assay and the sister chromatid exchange (SCE) test. Environ. Mol. Mutagen., 23, 299-305.

46. Rasmussen, R.E. and Menzel, D.B. (1997) Variation in arsenic-induced sister chromatid exchange in human lymphocytes and lymphoblastoid cell lines. Mutat. Res., 386, 299306.

47. Schaumloffel, N. and Gebel, T. (1998) Heterogeneity of the DNA damage provoked by antimony and arsenic. Mutagenesis, 13, 281-286.

48. Colognato, R., Coppede, F., Ponti, J., Sabbioni, E. and Migliore, L. (2007) Genotoxicity induced by arsenic compounds in peripheral human lymphocytes analysed by cytokinesis-block micronucleus assay. Mutagenesis, 22, 255261.

49. Avani, G. and Rao, M.V. (2007) Genotoxic effects in human lymphocytes exposed to arsenic and vitamin A. Toxicol. In Vitro, 21, 626-631.

50. Sordo, M., Herrera, L.A., Ostrosky-Wegman, P. and Rojas, E. (2001) Cytotoxic and genotoxic effects of As, MMA and DMA on leukocytes and stimulated human lymphocytes. Teratog., Carcinog. Mutagen., 21, 249-260.

51. Guillamet, E., Creus, A., Ponti, J., Sabbioni, E., Fortaner, S. and Marcos, R. (2004) In vitro DNA damage by arsenic compounds in a human lymphoblastoid cell line (TK6) assessed by the alkaline Comet assay. Mutagenesis, 19, 129135.

52. Yedjou, C.G. and Tchounwou, P.B. (2007) In-vitro cytotoxic and genotoxic effects of arsenic trioxide on human leukemia (HL-60) cells using the MTT and alkaline single cell gel electrophoresis (Comet) assays. Mol. Cell. Biochem., 301, 123-130.

53. Stevens, J.J., Graham, B., Walker, A.M., Tchounwou, P.B. and Rogers, C. (2010) The effects of arsenic trioxide on DNA synthesis and genotoxicity in human colon cancer cells. Int. J. Environ. Res. Public Health, 7, 2018-2032.

54. Salazar, A.M., Sordo, M. and Ostrosky-Wegman, P. (2009) Relationship between micronuclei formation and p53 induction. Mutat. Res., 672, 124-128.

55. Alarifi, S., Ali, D., Alkahtani, S., Siddiqui, M.A. and Ali, B.A. (2013) Arsenic trioxide-mediated oxidative stress and genotoxicity in human hepatocellular carcinoma cells. Onco Targets Ther., 6, 75-84.

56. Graham, B., Stevens, J., Wells, P., Sims, J., Rogers, C., Leggett, S.S., Ekunwe, S. and Ndebele, K. (2014) Enhancement of arsenic trioxide-mediated changes in human induced pluripotent stem cells (IPS) Int. J. Environ. Res. Public Health, 11, 7524-7536.

57. Xie, H., Huang, S., Martin, S. and Wise, J.P. (2014) Arsenic is cytotoxic and genotoxic to primary human lung cells. Mutat. Res., 760, 33-41.

58. Petres, J., Schmid-Ullrich, K. and Wolf, U. (1970) Chromosomenaberrationen an menschlichen Lymphozyten bei chro- 
nischen Arsenschäden. Dtsch. Med. Wochenschr., 95, 79-80.

59. Nordenson, I., Salmonsson, S., Brun, E. and Beckman, G. (1979) Chromosome aberrations in psoriatic patients treated with arsenic. Hum. Genet., 48, 1-6.

60. Burgdorf, W., Kurvink, K. and Cervenka, J. (1977) Elevated sister chromatid exchange rate in lymphocytes of subjects treated with arsenic. Hum. Genet., 36, 69-72.

61. Ostrosky-Wegman, P., Gonsebatt, M.E., Montero, R., Vega, L., Barba, H., Espinosa, J., Palao, A., Cortinas, C., GarciaVargas, G., Del Razo, L.M. and Cebrian, M. (1991) Lymphocyte proliferation kinetics and genotoxic findings in a pilot study on individuals chronically exposed to arsenic in Mexico. Mutat. Res., 250, 477-482.

62. Vig, B.K., Figueroa, M.L., Cornforth, M.N. and Jenkins, S.H. (1984) Chromosome studies in human subjects chronically exposed to arsenic in drinking water. Am. J. Ind. Med., 6, 325-338.

63. Beckman, G., Beckman, L. and Nordenson, I. (1977) Chromosome aberrations in workers exposed to arsenic. Environ. Health Perspect., 19, 145-146.

64. Nordenson, I., Beckman, G., Beckman, L. and Nordström, S. (1978) Occupational and environmental risks in and around a smelter in northern Sweden: II. Chromosomal aberrations in workers exposed to arsenic. Hereditas, 88, 47-50.

65. Hu, G.G. (1989) Investigation of protective effect of selenium on genetic materials among workers exposed to arsenic. Zhonghua Yu Fang Yi Xue Za Zhi, 23, 286-288.

66. Nilsson, R., Jha, A.N., Zaprianov, Z. and Natarajan, A.T. (1993) Chromosomal aberrations in humans exposed to arsenic in the Srednogorie area, Bulgaria. Fresen. Environ. Bull., 2, 59-64.

67. Lerda, D. (1994) Sister-chromatid exchange (SCE) among individuals chronically exposed to arsenic in drinking water. Mutat. Res., 312, 111-120.

68. Warner, M.L., Moore, L.E., Smith, M.T., Kalman, D.A., Fanning, E. and Smith, A.H. (1994) Increased micronuclei in exfoliated bladder cells of individuals who chronically ingest arsenic-contaminated water in Nevada. Cancer Epidemiol. Biomarkers Prev., 3, 583-590.

69. Dulout, F.N., Grillo, C.A., Seoane, A.I., Maderna, C.R., Nilsson, R., Vahter, M., Darroudi, F. and Natarajan, A.T. (1996) Chromosomal aberrations in peripheral blood lymphocytes from native Andean women and children from northwestern Argentina exposed to arsenic in drinking water. Mutat. Res., 370, 151-158.

70. Moore, L.E., Warner, M.L., Smith, A.H., Kalman, D.A. and Smith, M.T. (1996) Use of the fluorescent micronucleus assay to detect the genotoxic effects of radiation and arsenic exposure in exfoliated human epithelial cells. Environ. Mol. Mutagen., 27, 176-184.

71. Moore, L.E., Smith, A.H., Hopenhayn-Rich, C., Biggs, M.L., Kalman, D.A. and Smith, M.T. (1997) Micronuclei in exfoliated bladder cells among individuals chronically exposed to arsenic in drinking water. Cancer Epidemiol. Biomarkers Prev., 6, 31-36.

72. Biggs, M.L., Kalman, D.A., Moore, L.E., Hopenhayn-Rich, C., Smith, M.T. and Smith, A.H. (1997) Relationship of urinary arsenic to intake estimates and a biomarker of effect, bladder cell micronuclei. Mutat. Res., 386, 185-195.
73. Gonsebatt, M.E., Vega, L., Salazar, A.M., Montero, R., Guzman, P., Blas, J., Del Razo, L.M., Garcia-Vargas, G., Albores, A., Cebrian, M.E. and Kelsh, M. (1997) Cytogenetic effects in human exposure to arsenic. Mutat. Res., 386, 219-228.

74. Mäki-Paakkanen, J., Kurttio, P., Paldy, A. and Pekkanen, J. (1998) Association between the clastogenic effect in peripheral lymphocytes and human exposure to arsenic through drinking water. Environ. Mol. Mutagen., 32, 301-313.

75. Martínez, V., Creus, A., Venegas, W., Arroyo, A., Beck, J.P., Gebel, T.W., Surrallés, J. and Marcos, R. (2004) Evaluation of micronucleus induction in a Chilean population environmentally exposed to arsenic. Mutat. Res., 564, 65-74.

76. Martínez, V., Creus, A., Venegas, W., Arroyo, A., Beck, J.P., Gebel, T.W., Surralles, J. and Marcos, R. (2005) Micronuclei assessment in buccal cells of people environmentally exposed to arsenic in northern Chile. Toxicol. Lett., 155, 319-327.

77. Sampayo-Reyes, A., Hernández, A., El-Yamani, N., LópezCampos, C., Mayet-Machado, E., Rincón-Castañeda, C.B., Limones-Aguilar, M.D.L., López-Campos, J.E., de León, M.B., González-Hernández, S. and Hinojosa-Garza, D. (2010) Arsenic induces DNA damage in environmentally exposed Mexican children and adults. Influence of GSTO1 and AS3MT polymorphisms. Toxicol. Sci., 117, 63-71.

78. Mahata, J., Basu, A., Ghoshal, S., Sarkar, J.N., Roy, A.K., Poddar, G., Nandy, A.K., Banerjee, A., Ray, K., Natarajan, A.T. and Nilsson, R. (2003) Chromosomal aberrations and sister chromatid exchanges in individuals exposed to arsenic through drinking water in West Bengal, India. Mutat. Res., 534, 133-143.

79. Basu, A., Mahata, J., Roy, A.K., Sarkar, J.N., Poddar, G., Nandy, A.K., Sarkar, P.K., Dutta, P.K., Banerjee, A., Das, M. and Ray, K. (2002) Enhanced frequency of micronuclei in individuals exposed to arsenic through drinking water in West Bengal, India. Mutat. Res., 516, 29-40.

80. Basu, A., Som, A., Ghoshal, S., Mondal, L., Chaubey, R.C., Bhilwade, H.N., Rahman, M.M. and Giri, A.K. (2005) Assessment of DNA damage in peripheral blood lymphocytes of individuals susceptible to arsenic induced toxicity in West Bengal, India. Toxicol. Lett., 159, 100-112.

81. Yáñez, L., García-Nieto, E., Rojas, E., Carrizales, L., Mejía, J., Calderón, J., Razo, I. and Díaz-Barriga, F. (2003) DNA damage in blood cells from children exposed to arsenic and lead in a mining area. Environ. Res., 93, 231-240.

82. Paiva, L., Marcos, R., Creus, A., Coggan, M., Oakley, A.J. and Board, P.G. (2008) Polymorphism of glutathione transferase Omega 1 in a population exposed to a high environmental arsenic burden. Pharmacogenet. Genomics, 18, 1-10.

83. Dastgiri, S., Mosaferi, M., Fizi, M.A., Olfati, N., Zolali, S., Pouladi, N. and Azarfam, P. (2010) Arsenic exposure, dermatological lesions, hypertensionand chromosomal abnormalities among people in a rural community of northwest Iran. J. Health Popul. Nutr., 28, 14-22.

84. Bartolotta, S.A., Pacskowski, M.G., Hick, A. and Carballo, M.A. (2011) Micronuclei assay in exfoliated buccal cells from individuals exposed to arsenic in Argentina. Arch. Environ. Contam. Toxicol., 61, 337-343.

85. Gamiño-Gutiérrez, S.P., González-Pérez, C.I., Gonsebatt, M.E. and Monroy-Fernández, M.G. (2013) Arsenic and lead 
contamination in urban soils of Villa de la Paz (Mexico) affected by historical mine wastes and its effect on children's health studied by micronucleated exfoliated cells assay. Environ. Geochem. Health, 35, 37-51.

86. Chatterjee, D., Adak, S., Banerjee, N., Bhattacharjee, P.,
Bandyopadhyay, A.K. and Giri, A.K. (2018) Evaluatıon of health effects, genetic damage and telomere length in children exposed to arsenic in West Bengal, İndia. Mutat. Res., doi:10.1016/j.mrgentox.2018.06.012/. 